\title{
O XIII Congresso Internacional de Ciências Administrativas
}

\section{$\mathrm{O}$}

Instituto Internacional de Ciências Administrativas realizará o XIII Congresso que trancorrerá no período de 19 a 23 de julho do corrente ano, na Casa da UNESCO, em Paris.

Serão temas pertinentes à agenda dêste Congresso, versando todos sôbre assuntos de Administração Pública, os que abaixo se relacionam.

1 - Relações Públicas em Administração;

I - A influência do público na Operação de Administração Pública, excluindo-se assunto que trate de direito eleitoral.

2 - Novas Técnicas de preparação orçamentária e Chefia;

3 - Direção Administrativa de Emprêsas Públicas.

Serão efetuadas reuniöes especiais de Representantes de Es colas e Institutos de Administração Pública, tendo em vista debater-se o seguinte:

A função das Escolas e Institutos dedicados à Administração Pública e ao Desenvolvimento da Administração.

Informações mais minuciosas poderão ser obtidas por intermédio do Instituto Internacional de Ciências Administrativas, localizado: 25 Rue de la Charité, Bruxelles, Bélgica, Europa.

Do roteiro já traçado para aquêle congresso, cujo teor estamos publicando, acolheremos com prazer as teses que forem ali debatidas, com o fim de propiciar maior divulgação entre nós, das proveitosas conclusões a que levarem o evolver dêsse tão útil seminário. 